Tropical Journal of Pharmaceutical Research October 2018; 17 (10): 1977-1982

ISSN: $1596-5996$ (print); 1596-9827 (electronic)

(C) Pharmacotherapy Group, Faculty of Pharmacy, University of Benin, Benin City, 300001 Nigeria.

Available online at http://www.tjpr.org

Original Research Article

http://dx.doi.org/10.4314/tjpr.v17i10.12

\title{
Fatty acid constituents and anticancer activity of Cladophora fracta (OF Müller ex Vahl) Kützing
}

\author{
Tunay Karan ${ }^{1 *}$, Ramazan Erenler ${ }^{2}$ \\ ${ }^{1}$ Department of Molecular Biology and Genetics, ${ }^{2}$ Department of Chemistry, Faculty of Arts and Sciences, Tokat \\ Gaziosmanpasa University, 60240 Tokat, Turkey
}

*For correspondence: Email: biyo_tunay@hotmail.com; Tel: +90 356252 16 16/3070

Sent for review: 31 March 2018

Revised accepted: 22 September 2018

\begin{abstract}
Purpose: To determine the fatty acid constituents and anticancer effect of Cladohora fracta Methods: Cladophora fracta (O.F. Müller ex Vahl) Kützing was collected from natural ponds in Tokat, Turkey. Antiproliferative and cytotoxic effects of methanol and hexane extracts of $\mathrm{C}$. fracta were investigated on human colon carcinoma (HT29) and non-tumorigenic African green monkey kidney (Vero) cell lines using BrdU cell proliferation enzyme-linked Immunosorbent assay (ELISA) and lactate dehydrogenase (LDH) test, respectively. The fatty acid composition of hexane extract was analyzed by gas chromatography-mass spectrometry (GC-MS).

Results: Oleic acid, palmitic acid, gamma-linoleic acid and linoleic acid were the main constituents of $C$. fracta. The methanol extract exhibited strong antiproliferative activity on HT29 and Vero cell lines ( $p<$ 0.05). The hexane extract revealed its good antiproliferative activity at high concentrations on both cell lines. Cytotoxicity results showed that both methanol and hexane extract had low effect on HT29 cell at low concentrations.

Conclusion: Due to the strong antiproliferative effect of $C$. fracta methanol extract on HT29 and Vero cell lines, it has potential anticancer properties and recommended for further development as such.
\end{abstract}

Keywords: Cladophora fracta, Antiproliferative activity, Anti-cancer, Cytotoxic effect, Fatty acid

\begin{abstract}
This is an Open Access article that uses a funding model which does not charge readers or their institutions for access and distributed under the terms of the Creative Commons Attribution License (http://creativecommons.org/licenses/by/4.0) and the Budapest Open Access Initiative (http://www.budapestopenaccessinitiative.org/read), which permit unrestricted use, distribution, and reproduction in any medium, provided the original work is properly credited.
\end{abstract}

Tropical Journal of Pharmaceutical Research is indexed by Science Citation Index (SciSearch), Scopus, International Pharmaceutical Abstract, Chemical Abstracts, Embase, Index Copernicus, EBSCO, African Index Medicus, JournalSeek, Journal Citation Reports/Science Edition, Directory of Open Access Journals (DOAJ), African Journal Online, Bioline International, Open-J-Gate and Pharmacy Abstracts

\section{INTRODUCTION}

Natural products play a considerable role in drug development processes, due to bioactive secondary metabolites in their compositions [17]. Bioactive compounds from algae with efficient medicinal potential attract a significant amount of attention in cancer research. Algae have been known as one of the most effective groups of organisms to isolate bioactive natural compounds. Phytochemical research on algae leads to isolation of fascinating secondary metabolites with various biological effects such as antitumor, antifungal, antioxidant, antibiotic, anti-HIV, antimicrobial, anti-inflammatory, herbicidal, immune-suppressive activities [8].

Cancer is a major public health problem and is the leading cause of human death all over the world. Cancer is uncontrolled cell growth which can kill normal cells or spread quickly to all body parts [9]. Taking into account the increasing 
cancer incidence rates, safe and effective treatment is crucially needed to inhibit tumor cell proliferation. Nowadays, chemotherapeutic medicines are being used effectively in cancer therapy. However, chemotherapeutic medicines have heavy toxicity and side effects. Therefore, there is an interest in natural agents for cancer treatment [10].

Algae have been extensively used as a food additive and for medicinal purposes. Since some algae have been used in treatment of cancers, many crude extracts and isolated compounds from algae have been investigated for their anticancer effects and these studies revealed that algae contain some novel compounds with therapeutic properties for human diseases [11].

In a previous work, the good inhibitory activities of Mougeotia nummuloides and Spirulina major on different cancer cell lines were demonstrated [12]. In the present study, the anticancer and cytotoxic activities of Cladophora fracta extracts have been investigated along with the fatty acid constituents of the hexane extract.

\section{EXPERIMENTAL}

\section{Collection and identification}

Cladophara fracta was collected from Tokat Gaziosmanpasa University Campus during the spring of 2015 . The alga material was washed with water to get rid of epiphytes, invertebrates, extraneous material. After the addition of $5 \%$ formalin to the alga specimen, identification was executed with a light microscope [13].

\section{Extraction of $C$. fracta}

The air dried C. fracta $(10 \mathrm{~g})$ was powdered and extracted with $100 \mathrm{ml}$ of hexane for $24 \mathrm{~h}$ and the filtration was executed by a Buchner funnel with a filter paper. Then, $C$. fracta hexane extract was re-extracted with methanol $(100 \mathrm{~mL})$. After filtration, the solvents were removed by a rotary evaporator to yield the hexane extract and methanol extract which were stored $\left(+4^{\circ} \mathrm{C}\right)$ for further analysis.

\section{Esterification of hexane extract}

The hexane extract (35 mg) was dissolved in hexane $(5.0 \mathrm{~mL})$ and centrifuged at $3500 \mathrm{rpm}$ for $3 \mathrm{~min}$. The supernatant $(3 \mathrm{~mL})$ was poured to a glass tube. $3 \mathrm{~mL}$ of $\mathrm{KOH}$ ( $2 \mathrm{M}$ in methanol) was added and vigorously shaken. The upper layer was directly injected to Gas chromatographyflame ionization detector (GC-FID).

\section{GC-FID analysis}

Fatty acid analysis was carried out on an instrument (Perkin Elmer Clarus 500) with RTX2330 (Restek) capillary column $(30 \mathrm{~m} \times 0.25 \mathrm{~mm}$ id., $\times 0.20 \mu \mathrm{m}$ film thickness). Helium was used as beared gas at a flow rate of $1 \mathrm{~mL} / \mathrm{min}$ with $50 / 1$ split ratio. The detector and injection temperatures were 250 and $37^{\circ} \mathrm{C}$, respectively. Fatty acid methyl ester mixtures were used as standards to identify fatty acids.

\section{Preparation of cell culture}

Anticancer effects of $C$. fracta extracts were examined on various cell lines such as cancerous HT29 (ATCCR HTB-38 ${ }^{\text {TM}}$ ) and noncancerous Vero cells (ATCCR CCL-81 TM). The cultivation was executed in Dulbecco's modified eagle's cell medium (DMEM) supplemented with fetal bovine serum $(10 \%, v / v)$ and PenicillinStreptomycin solution $(2 \%, v / v)$. Old medium was removed from plates when cells achieved a congestion of $85 \%$. Then, cells were ripped from flask using trypsin-EDTA $(4.0 \mathrm{~mL})$ (Sigma, Germany). Finally, the cell pellet was resuspended using DMEM $(4.0 \mathrm{~mL})$ and counted to achieve a concentration of $5 \times 10^{4}$ cell $/ \mathrm{mL}$ and inoculation was executed in wells [4].

\section{BrdU proliferation assay}

A cell suspension of roughly $5 \times 10^{3}$ cells in 100 $\mu \mathrm{L}$ was inoculated into the wells of culture plates. C. fracta extracts and standard (5 fluorouracil, $5 \mathrm{FU})$ were dissolved in DMSO (0.5\%), and then were treated with cells at the concentrations of 5 , $10,20,30,40,50,75$, and $100 \mathrm{mg} / \mathrm{mL}$ at $37^{\circ} \mathrm{C}$ overnight. DMEM was applied to adjust the final volume to $200 \mu \mathrm{L}$. The measurement of cell proliferation was executed by ELISA Kit (Roche, USA). Microplate reader was employed to evaluate the BrdU incorporation at $450-600 \mathrm{~nm}$ and each trial was carried out three times [5].

\section{Calculation of $\mathrm{IC}_{50}$ and $\%$ inhibition}

XLfit5 software was carried out to calculate the half maximal inhibitory concentration $\left(\mathrm{IC}_{50}\right)$. Inhibition was calculated as in Eq 1.

Inhibition $(\%)=\{(\mathrm{A}-\mathrm{B}) / \mathrm{B}\} 100$

where $A$ is the absorbance of the extracts and $B$ the absorbance of DMSO.

\section{Evaluation of cytotoxic activity}

The cytotoxicity of hexane extract and methanol extract as well as fluorouracil were carried out on 
HT29 and Vero cells using a Lactate Dehydrogenase Assay Kit (Roche, USA). Nearly $5 \times 10^{3}$ cells in $100 \mu \mathrm{L}$ were placed into microtiter plates and reacted with diverse concentrations of $C$. fracta extracts. LDH activity was detected at 492 - $630 \mathrm{~nm}$ using a microplate reader [14]. The cytotoxicity results were calculated by Eq 2 .

Cytotoxicity $(\%)=\{(E V-L C / H C-L C o) \times 100\}$ ...... (2)

where $\mathrm{EV}=$ experimental value, $\mathrm{LC}=$ low control, and $\mathrm{HC}=$ high control.

\section{Assessment of cell morphology}

Cells were set up in plates at a density of 5.000 cells per well and kept for $24 \mathrm{~h}$. Morphological changes of the cells were observed by a phase microscope (phase contrast) in every 6 hours for $24 \mathrm{~h}$. The sights of extracts and standard treated with the cells were photographed by a digital camera combined with an inverted microscope.

\section{Statistical analysis}

Statistical analysis was performed using Statistical Package for Social Sciences (Windows version 21.0, SPSS). The data were reported as mean \pm standard deviation. Differences between groups were considered significant at the 5\% probability level.

\section{RESULTS}

\section{Fatty acid content}

After esterification of hexane extract, fatty acid constituents were determined using GC-MS analysis (Table 1). Oleic acid (46.0\%), palmitic acid (15.6\%), gamma linoleic acid (10.6\%), linoleic acid (7.5\%) were found as main constituents. In addition, lauric acid, myristic acid, pentadecanic acid, palmitoleic acid were detected in hexane extract of Cladophora fracta.

\section{Antiproliferative activity}

Antiproliferative effects of $C$. fracta hexane and methanol extracts were carried out on Vero and HT29 cell lines using BrdU Cell Proliferation ELISA kit, with 5FU as a positive control for anticancer activity (Figure 1). XLfit5 software was applied for determination of $\mathrm{IC}_{50}$ values (Table 2 ).

C. fracta methanol extract showed higher activity than $5 \mathrm{FU}$ (Table 2). On the other hand, activity of hexane extract was not more effective than $5 \mathrm{FU}$ on cell lines. Methanol extract displayed higher tumor specificity on HT29 cell lines than hexane extract.

Table 1: Fatty acid constituents of Cladophora fracta

\begin{tabular}{llc}
\hline RT (min) & Fatty acid & Area (\%) \\
\hline 7.149 & C12:0 (Lauric acid) & 0.42 \\
11.419 & C 14:0 (Myristic acid) & 4.46 \\
14.047 & C15:0 (Pentadecanoic acid) & 0.29 \\
16.923 & C16:0 (Palmitic acid) & 15.56 \\
18.163 & C16:1 (Palmitoleic acid) & 1.54 \\
21.487 & C17:1 (cis-10-Heptadecenoic & 0.70 \\
& acid) & \\
22.875 & C18:0 (Stearic acid) & 2.21 \\
24.299 & C18:1n9c (Oleic acid) & 45.99 \\
25.900 & C18:2n6t (Linolelaid acid) & 0.54 \\
26.536 & C18:2n6c ((Linoleic acid) & 7.53 \\
28.865 & C20:0 (Arachidic acid) & 0.25 \\
29.292 & C18:3n6 (gama Linoleic & 10.66 \\
& acid) & \\
34.750 & C20:3n3 (Eicosatrienoic acid & 1.02 \\
& methylester) & \\
35.390 & C22:1n9 (Erucic acid) & 0.22 \\
36.886 & C20:5n3 (Eicosatrienoic acid & 8.37 \\
& methylester) & \\
\hline
\end{tabular}

Table 2: Half Maximal Inhibitory Concentration $\left(\mathrm{IC}_{50}\right)$ values for $C$. fracta extracts and control

\begin{tabular}{|c|c|c|c|}
\hline \multirow[b]{2}{*}{ Sample } & \multicolumn{3}{|c|}{$\mathrm{IC}_{50} \pm \mathrm{SD}(\mu \mathrm{g} / \mathrm{mL})$} \\
\hline & HT29 & Vero & $\begin{array}{c}\text { Tumor } \\
\text { specificity }\end{array}$ \\
\hline Hexane & $35.04 \pm 1.3$ & $27.28 \pm 1.0$ & 0.78 \\
\hline $\begin{array}{l}\mathrm{MeOH} \\
5 \mathrm{FU}\end{array}$ & $\begin{array}{l}14.84 \pm 0.9 \\
21.58 \pm 1.1\end{array}$ & $\begin{array}{l}14.16 \pm 0.8 \\
20.55 \pm 1.0\end{array}$ & $\begin{array}{l}0.95 \\
0.95\end{array}$ \\
\hline
\end{tabular}

Both extracts were found to have significant effects on HT29 cell lines to some degree. Activity of methanol extract was higher than 5FU at all concentrations. Nevertheless, hexane extract displayed lower activity up to $50 \mu \mathrm{g} / \mathrm{mL}$. In Vero Cell lines, methanol extract showed the same activity as $5 F U$ up to $20 \mu \mathrm{g} / \mathrm{mL}$. Its inhibition increased after $20 \mu \mathrm{g} / \mathrm{mL}$. In regard to hexane extract, it displayed good activity at high concentrations as usual (Figure 1).

\section{Cytotoxicity}

Cytotoxicity of $C$. fracta hexane and methanol extracts were tested on cell lines via LDH cytotoxicity assay kit. Cytotoxicity was evaluated by treating cells with various concentrations of $C$. fracta extracts $(5,10,20,30,40,50,75,100$ $\mu \mathrm{g} / \mathrm{mL}$ ) that displayed breakdown of cell membrane with the concentration dependence. The cytotoxicity tests revealed that reaction of cells with higher concentrations of hexane and methanol extracts of $C$. fracta brought about cell membrane damage but at low concentration 
significant cytotoxicity was not detected. Interestingly, both hexane and methanol extracts of $C$. fracta were safest for HT29 cell line at 40 $\mu \mathrm{g} / \mathrm{mL}$ and below dose while were highly toxic after $30 \mu \mathrm{g} / \mathrm{mL}$ for other cell lines. C. fracta extracts exhibited cytotoxic effect at high concentrations. So $C$. fracta has therapeutic properties (Figure 2).
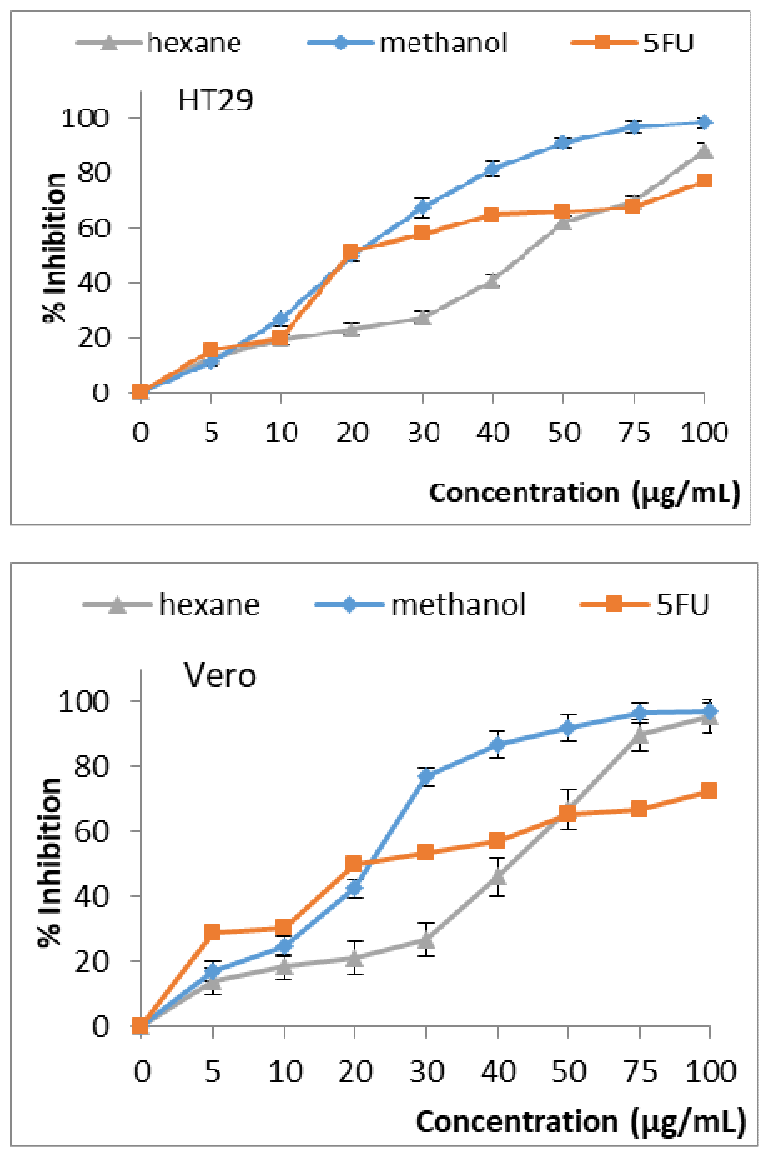

Figure 1: Antiproliferative effect of hexane, methanol extract and 5FU on HT29 and Vero cell lines

\section{Morphological features}

Morphological assessment of cytotoxic activity of C. fracta hexane and methanol extracts (Figure 3) were executed with a digital camera combined with an inverted microscope (Germany, Leice IL10). Treatment of cells with extracts changed the shape of cells from round to floating form, indicating the death of cells at high concentration. At low concentrations, these extracts did not affect the growth of cells. Activity of methanol extract was better than that of the hexane extract.

\section{DISCUSSION}

Freshwater environment has a great potential for discovery of bioactive compounds that could be used in pharmaceutical industries [15].
Especially, green algae harbor considerable amount of bioactive compounds which display a great deal of biological activity [16]. In addition, Cladophora species consist of the free sterols, their esters and glycosides [17].
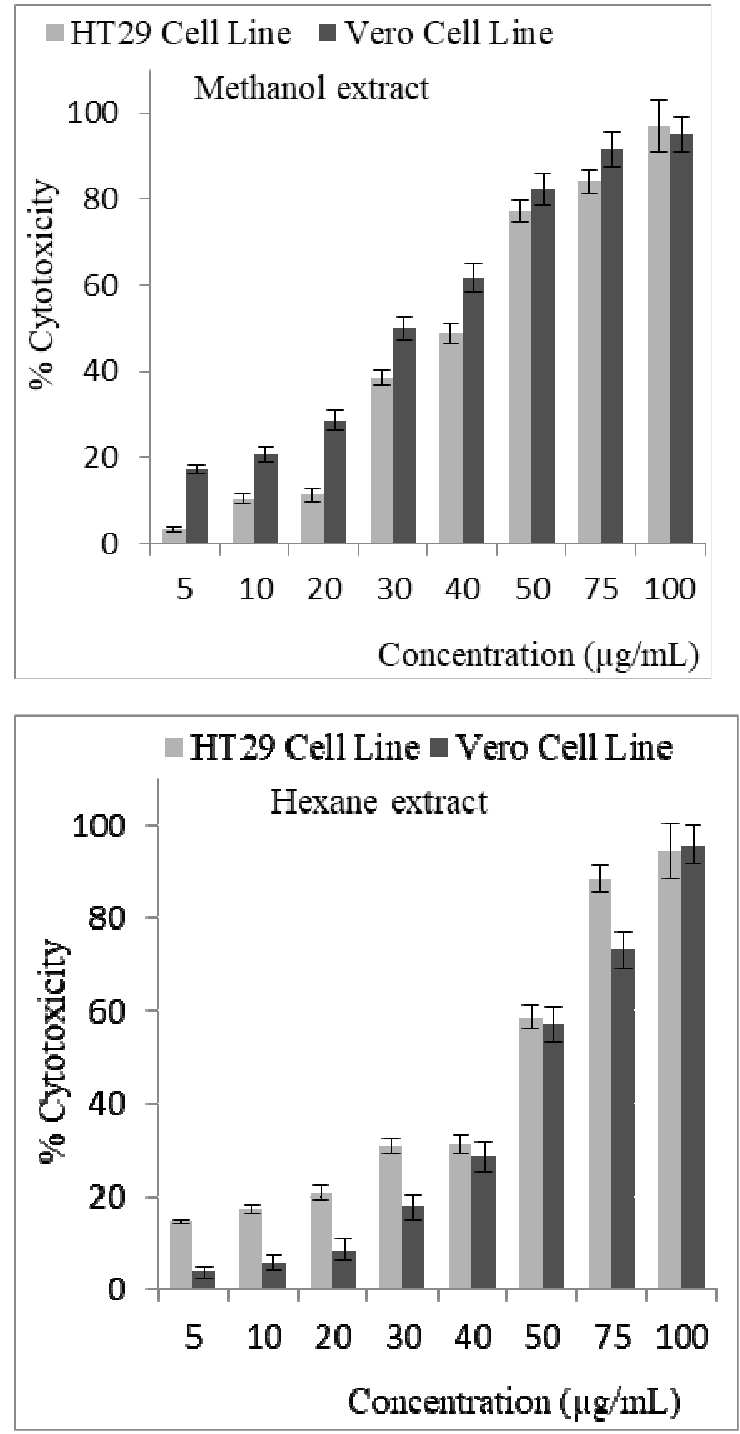

Figure 2: Cytotoxic activity of extracts on HT29 and Vero cell lines.

In the present study, Cladophora fracta methanol extract could be promising source of drug development process due to the fact that it displays higher antiproliferative effects of methanol extract than standard $5 \mathrm{FU}$ on Vero and HT29 cell lines. In addition; hexane extract also displayed as good an activity as standard on all cell lines. This has to do with fatty acid contents. Fatty acids are abundant in algae species and have significant biological activities such as antiviral, anti-inflammatory [18], anticancer [19] and antimicrobial [20] activities. Two fatty acids, $18: 4 n-3$ and 16:4n-3, were isolated from marine algae Ulva pertusa and Ulva pinnatifida and found to have strong inhibitory effects on 
Hexane extract
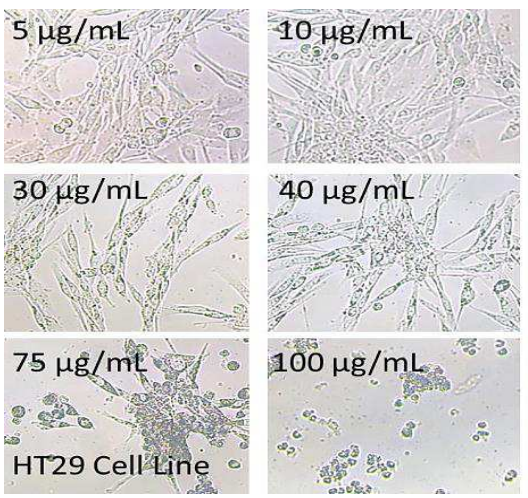

5. $\mathrm{\mu g} / \mathrm{mL}$

$10 \mu \mathrm{g} / \mathrm{mL}$

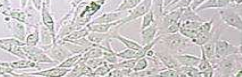

$30 \mu \mathrm{g} / \mathrm{mL}$

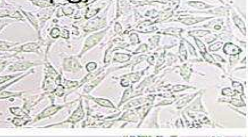

$75 \mu \mathrm{g} / \mathrm{mL}$

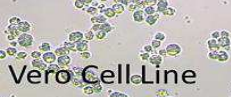

Methanol extract
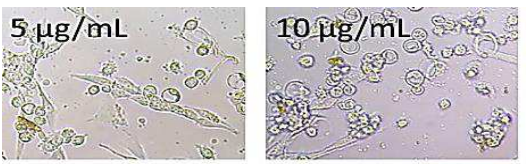

HT29 Cell Line

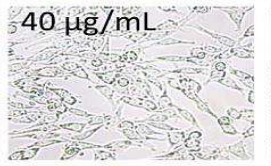

$50 \mu \mathrm{g} / \mathrm{mL}$
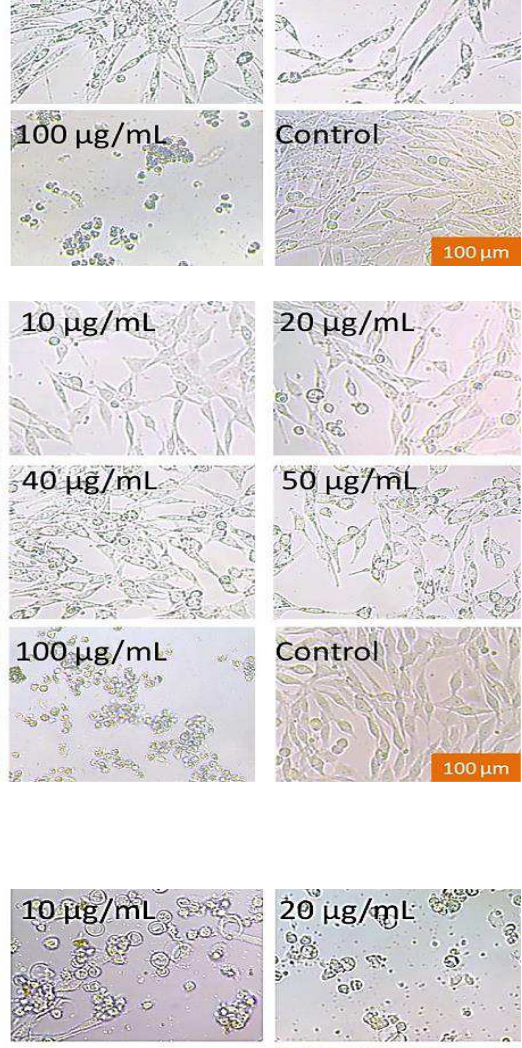

Control
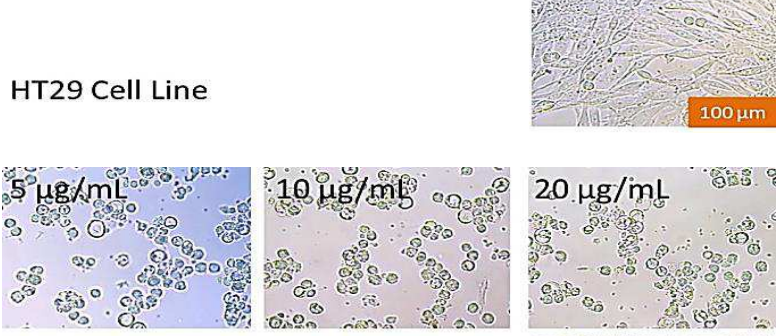

Vero Cell Line

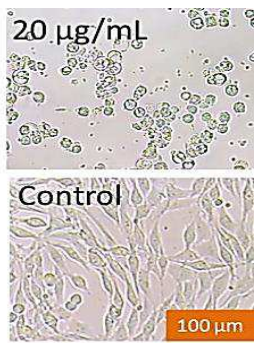

Figure 3: Effect of $C$. fracta extracts on the morphology of HT29 and Vero cells. DMSO treated cells as controls

Lekotrien B4, 5-hydroxyeicsatetraenoic acid and leukotriene $\mathrm{C} 4$ in MC/9 mice mast cells [21]. Fatty acids have inhibitory effects on tumor growth and antimetastatic property. They are able to change malignant cell membranes to serve chemotherapy effects [22]. Oleic acid plays a significant role in activation of various intracellular pathways such as carcinoma cell development. Palmitic acid also showed considerable antitumor effect in mice [23]. $y$ linolenic acid suppressed cell growth of neuroblastoma cell lines [24]. Linolenic acid gained great attention as a chemotherapeutic agent after being displayed to have inhibitory effects on carcinogenesis [25].

\section{CONCLUSION}

C. fracta exhibits antiproliferative effect on HT29 and Vero cell lines. There is a need, however, to isolate and identify the active chemical compounds of $C$. fracta. The fatty acid contents also displayed strong antiproliferative activity on HT29 and Vero cell lines as well. Further studies are required to determine the potentials of both the extract and its fatty acid for anti-cancer therapy.

\section{DECLARATIONS}

\section{Acknowledgement}

The authors are grateful to Dr. Ali Aydin for executing the antiproliferative activity tests and Dr. Nejdet Kandemir for his critical review of the manuscript.

\section{Conflict of Interest}

No conflict of interest associated with this work.

\section{Contribution of Authors}

The authors declare that this work was done by the authors named in this article and all liabilities pertaining to claims relating to the content of this article will be borne by them.

\section{REFERENCES}

1. Demirtas I, Erenler R, Elmastas $M$ and Goktasoglu $A$. Studies on the antioxidant potential of flavones of Allium vineale isolated from its water-soluble fraction. Food Chem 2013; 136(1): 34-40.

2. Elmastas $M$, Erenler $R$, Isnac $B$, Aksit $H$, Sen $O$, Genc $N$ and Demirtas I. Isolation and identification of a new neoclerodane diterpenoid from Teucrium chamaedrys $L$. Nat Prod Res 2016; 30(3): 299-304.

3. Elmastaş M, Telci $I$, Akşit $H$ and Erenler R. Comparison of total phenolic contents and antioxidant capacities in mint genotypes used as spices/Baharat olarak kullanılan nane genotiplerinin toplam fenolik içerikleri ve antioksidan kapasitelerinin karşılaştırılması. Turk $J$ Biochem 2015; 40(6): 456-462.

4. Erenler $R$, Meral B, Sen O, Elmastas M, Aydin A, Eminagaoglu $O$ and Topcu G. Bioassay-guided isolation, identification of compounds from Origanum 
rotundifolium and investigation of their antiproliferative and antioxidant activities. Pharm Biol 2017; 55(1): 1646 1653.

5. Erenler $R$, Sen O, Yaglioglu AS and Demirtas I. Bioactivity-guided isolation of antiproliferative sesquiterpene lactones from Centaurea solstitialis $L$. ssp. solstitialis. Comb Chem High Throughput Screen 2016; 19(1): 66-72.

6. Erenler R, Yilmaz S, Aksit H, Sen O, Genc N, Elmastas $M$ and Demirtas I. Antioxidant activities of chemical constituents isolated from Echinops orientalis Trauv. Rec Nat Prod 2014; 8(1): 32-36.

7. Aksit H, Celik SM, Sen O, Erenler R, Demirtas I, Telci I and Elmastas M. Complete isolation and characterization of polar portion of Mentha dumetorum water extract. Rec Nat Prod 2014; 8(3): 277-280.

8. Burja AM, Banaigs B, Abou-Mansour E, Burgess JG and Wright PC. Marine cyanobacteria-a prolific source of natural products. Tetrahedron 2001; 57(46): 9347-9377.

9. Ferlay J, Soerjomataram I, Dikshit R, Eser S, Mathers C, Rebelo M, Parkin DM, Forman D and Bray F. Cancer incidence and mortality worldwide: sources, methods and major patterns in GLOBOCAN 2012. Int J Cancer 2015; 136(5): E359-386.

10. Pereira DM, Cheel J, Areche $C$, San-Martin A, Rovirosa $J$, Silva LR, Valentao $P$ and Andrade $P B$. Antiproliferative activity of Meroditerpenoids isolated from the Brown alga Stypopodium flabelliforme against Several Cancer Cell Lines. Mar Drugs 2011; 9(5): 852862.

11. Moussavou G, Kwak DH, Obiang-Obonou BW, Maranguy $C A$, Dinzouna-Boutamba SD, Lee DH, Pissibanganga OG, Ko K, Seo Jl and Choo YK. Anticancer effects of different seaweeds on human colon and breast cancers. Mar Drugs 2014; 12(9): 4898-4911.

12. Erenler R, Pabuccu K, Yaglioglu AS, Demirtas I and Gul $F$. Chemical constituents and antiproliferative effects of cultured Mougeotia nummuloides and Spirulina major against cancerous cell lines. Z Naturforsch C 2016; 71(3-4): 87-92.

13. John DM, Whitton BA and Brook AJ. The Freshwater Algal Flora of the British Isles. An Identification Guide to Freshwater and Terrestrial Algae. UK, Cambridge University Press, 2002.

14. Okten S, Erenler R, Kul Koprulu $T$ and Tekin Ş. In vitro antiproliferative/cytotoxic activity of 2,3'-biindole against various cancer cell lines. Turk J Biol 2015; 39: 15-22.
15. Pearson L, Mihali T, Moffitt M, Kellmann $R$ and Neilan $B$. On the chemistry, toxicology and genetics of the cyanobacterial toxins, microcystin, nodularin, saxitoxin and cylindrospermopsin. Mar Drugs 2010; 8(5): 16501680.

16. El Gamal AA. Biological importance of marine algae. Saudi Pharm J 2010; 18(1): 1-25.

17. Elenkov I, Georgieva $T$, Hadjieva $P$, DimitrovaKonaklieva $S$ and Popov S. Terpenoids and sterols in Cladophora vagabunda. Phytochemistry 1995; 38(2): 457-459.

18. Poland M, Ten Klooster JP, Wang Z, Pieters $R$, Boekschoten $M$, Witkamp $R$ and Meijerink J. Docosahexaenoyl serotonin, an endogenously formed $n$-3 fatty acid-serotonin conjugate has anti-inflammatory properties by attenuating IL-23-IL-17 signaling in macrophages. Biochim Biophys Acta 2016; 1861(12 Pt A): 2020-2028.

19. Miccadei S, Masella R, Mileo AM and Gessani S. omega3 Polyunsaturated Fatty Acids as Immunomodulators in Colorectal Cancer: New Potential Role in Adjuvant Therapies. Front Immunol 2016; 7: 486

20. Butt U, EIShaer A, Snyder LA, Chaidemenou A and Alany RG. Fatty acid microemulsion for the treatment of neonatal conjunctivitis: quantification, characterisation and evaluation of antimicrobial activity. Drug Deliv Transl Res 2016; 6(6): 722-734.

21. Ishihara K, Murata M, Kaneniwa M, Saito H, Shinohara $K$ and Maeda-Yamamoto M. Inhibition of icosanoid production in MC/9 mouse mast cells by $n-3$ polyunsaturated fatty acids isolated from edible marine algae. Biosci Biotechnol Biochem 1998; 62(7): 14121415.

22. Johnson CD and Imrie CW. Pancreatic Disease: Towards the Year 2000. Springer Science \& Business Media, 2012.

23. Harada H, Yamashita U, Kurihara H, Fukushi E, Kawabata $J$ and Kamei $Y$. Antitumor activity of palmitic acid found as a selective cytotoxic substance in a marine red alga. Anticancer Res 2001; 22(5): 25872590.

24. Fujiwara F, Todo S and Imashuku S. Antitumor effect of $y$-linolenic acid on cultured human neuroblastoma cells. Prostaglandins Leukot Med 1986; 23(2-3): 311-320.

25. Belury MA. Inhibition of carcinogenesis by conjugated linoleic acid: potential mechanisms of action. J Nutrit 2002; 132(10): 2995-2998. 